\title{
Do $\mathrm{ZnO}$ and $\mathrm{Al}_{2} \mathrm{O}_{3}$ Nanoparticles Improve the Anti-Bacterial Properties of Cellulose Acetate-Chitosan Membrane?
}

\author{
Titik Istirokhatun ${ }^{\mathrm{a}, \mathrm{b},}$, , Ulva Yuni $^{\mathrm{a}}$, Pertiwi Andarani ${ }^{\mathrm{a}}$, Heru Susanto ${ }^{\mathrm{b}, \mathrm{c}}$ \\ ${ }^{a}$ Department of Environmental Engineering, Diponegoro University, Indonesia \\ ${ }^{b}$ Membrane Research Center(Mer-C), Center of Research and Services-Diponegoro University \\ 'Department of Chemical Engineering, Faculty of Engineering, Diponegoro University
}

\begin{abstract}
Biofouling, due to the existence of bacteria in water, becomes one of the barriers in cellulose acetate (CA) membrane applications. Although chitosan has been incorporated into CA membranes, its antimicrobial activity has not been improved significantly yet. In this study, cellulose acetate-chitosan membranes were prepared by modification using $\mathrm{ZnO}$ and $\mathrm{Al}_{2} \mathrm{O}_{3}$ nanoparticles during phase separation method. The membranes were then characterized in term of water permeability, and surface morphology. The anti-bacteria property was examined by using gram-negative bacteria. Modification of cellulose acetate-chitosan membranes with $\mathrm{ZnO}$ and $\mathrm{Al}_{2} \mathrm{O}_{3}$ nanoparticles have not shown optimal results where no clear zones around the membrane are visible.
\end{abstract}

\section{Introduction}

Membrane technology has been proposed as promising technology in the last few centuries to remove various contaminants from water and waste water [1-3]. Cellulose acetate $(\mathrm{CA})$ is considered as an attractive raw material for the membrane preparation due to its raw material availability in large quantities that commonly found in nature. CA membrane has been widely developed due to its superior characteristics such as nontoxic, inexpensive, biodegradable (therefore, they are susceptible to fouling) $[4,5]$.

Fouling membrane is a critical problem that inhibits membrane performance in water treatment processes and until now it has not yet handled. The main consequence of biofouling is the decrease of flux during filtration process [6,7]. Membrane fouling can be distinguished by organic fouling, inorganic fouling, and biological fouling (i.e., biofilm formation) [8]. Between these types of fouling, membrane biofouling, the accumulation of microorganisms and extracellular polymers on the membrane surface, is the major problem in water treatment. Membrane biofouling is formed when adhesion occurs from one or more bacteria on the membrane surface. Then it followed by growth and multiplication of sessile cells, which then form biofilms on the membrane surface $[9,10]$. Unlike physical and chemical fouling, biofouling is more difficult to be removed and it causes decrease in permeability, resulting in irreversible damage to membrane [11].

Chitosan (CS), also known as the most important derivative of chitin, which is its existence very abundant in Indonesia. Chitosan has been already used in membrane production due to its interesting characteristics such as hydrophilicity [12], non-toxicity [13], and antimicrobial activity [14].

Previous research has added chitosan to improve antibiofouling performance on cellulose acetate membranes. Unfortunately, it resulted low antimicrobial activity because the membrane loses its positive charge [15]. Another researcher stated that chitosan increased the membrane resistance against microbial fouling, but its microbial activity could only be seen via membrane surface visualization, and could not be seen by inhibition method. Furthermore, addition of chitosan also reduced the hydrophilicity of CA membrane [16]. Therefore, alternatives are needed for preventing biofouling, increasing hydrophilicity, and in the same time improving antibacterial activity of CA-CS membrane. Membrane modification using additives such as inorganic nanoparticles, is one of the alternative ways to control biofouling by improving basic polymer properties such as hydrophilicity and fouling resistance (perm-selectivity) $[17,18]$.

In this study, $\mathrm{Al}_{2} \mathrm{O}_{3}$ was used to enhance the mechanical resistance and hydrophilicity of the membrane [19]. $\quad \mathrm{Al}_{2} \mathrm{O}_{3}$ nanoparticle also improves membrane anti-adhesive capability thus reducing the biofilm layer and in the same time increasing membrane hydrophilicity [20].

Zink oxide is another material which is completely hydrophilic and possesses antibacterial nature. Moreover, $\mathrm{ZnO}$ also have ultravioresistant property which might potential benefit the antifouling performance of membrane. However, little attention is paid to the application of $\mathrm{ZnO}$ on membrane fabrication [21]. Therefore, the $\mathrm{ZnO}$ was also used in this study to improve

* Corresponding author: titik.istirokhatun@live.undip.ac.id 
hydrophilicity and antifouling properties of membranes [22-25].

In this research, modifications of cellulose acetatechitosan membranes were prepared by adding $\mathrm{Al}_{2} \mathrm{O}_{3}$ ( 0 $4 \%)$, and $\mathrm{ZnO}(0-4 \%)$ to improve the hydrophilicity and anti-biofouling properties of membranes.

\section{Materials and Methods}

\subsection{Materials}

Commercial cellulose acetate $\left(\left(\mathrm{C}_{6} \mathrm{H}_{7} \mathrm{O}_{2}\left(\mathrm{OCOCH}_{3}\right)\right) x\right.$ was purchased from from Sigma Aldrich, Germany. Nanoparticles $\mathrm{Al}_{2} \mathrm{O}_{3}$ and $\mathrm{ZnO}$ were obtained from Merck, Germany. Chitosan $\left(\mathrm{C}_{6} \mathrm{H}_{11} \mathrm{NO}_{4}\right) \mathrm{n}$ was purchased from Biotech Surendo, Indonesia. Acetic acid $\left(\mathrm{CH}_{3} \mathrm{COOH}\right)$ was obtained from Merck, Germany. Distilled water produced from home-made pure water unit was used for all experiment. Escherichia coli bacteria cultures were obtained from Microbiology, Diponegoro University.

\subsection{Methods}

\subsubsection{Membrane preparation}

Preparation of membrane was conducted by wet phase inversion. Membrane casting solution was made from $12 \%$ cellulose acetate as membrane base material, a mixture of acetic acid and distilled water (3:1) as solvent, $0.1 \%$ chitosan, nanoparticles $\mathrm{Al}_{2} \mathrm{O}_{3}$ and $\mathrm{ZnO}$ with concentration of $0-4 \%$ as additives.

First of all, chitosan was introduced into the solvent and stirred using a magnetic stirrer until all chitosan dissolved. Then the nanoparticles were added to the solution with concentration variations of $0-4 \%$ until dissolved. The final step was addition cellulose acetate then stirring until all the ingredients were homogenously mixed. After completion, casting solution was left without stirring until no bubble was observed.

Membrane molding process was carried out by following the method which has been conducted by Istirokhatun et al. [26] as follows, the solution was firstly cast on a glass substrate using a casting knife, then left in room temperature. Thereafter, the cast membrane was solidified in a coagulation bath containing water for 30 min to remove remained acidity. The resulting membrane was washed and rinsed by soaking in water for at least 24 $\mathrm{h}$ before drying.

\subsubsection{Membrane Characterizations}

The water permeability of the membranes was evaluated through a series of filtration using dead end stirred cell filtration system (Amicon model 8010), which was pressurized by nitrogen gas. Prior to each filtration membrane were pre-compacted by filtration of pure water at high pressure for at least $0.5-1 \mathrm{~h}$ to avoid effect of compaction. Thereafter, the pressure was lowered to the desired pressure for water permeability measurements (1 bar). The next step was measuring the permeate weight to know the volume. This permeate volume was then used as basis for calculating water flux. The equations used to calculate the pure water flux are:

$$
J=\frac{Q}{A . t}
$$

Where: Q : The volume of fluid passing through the membrane (permeate) (L)

$\mathrm{t}$ : Time (hour)

$\mathrm{J}$ : $\quad$ Flux $\left(\mathrm{L} / \mathrm{m}^{2}\right.$.hour $)$

A : Membrane Area $\left(\mathrm{m}^{2}\right)$

\subsubsection{Antibacterial activity test}

The antibacterial activity of the membrane was examined by an inhibition method, wherein gram-negative bacteria Escherichia Coli was used. This method has already been described by Istirokhatun et al and Ma et al $[16,27]$. To determine antibacterial activity, all membranes were sterilized in autoclave at $121^{\circ} \mathrm{C}, 2$ bars for $15 \mathrm{~min}$. Sterilized membranes were then placed on the surface nutrient agar (NA) containing Escherichia Coli solution and then incubated for 24 hours at $37^{\circ} \mathrm{C}$. The diameter of the clear zone formed around the membrane was noted as an indicator of antibacterial activity.

\section{Result and Discussion}

\subsection{Membrane Characterization}

\subsubsection{Effect of nanoparticles concentration on water permeability}

Membrane permeability can be determined by measuring flux. The results of the pure water flux test from Cellulose Acetate-Chitosan (CA-CS) membrane modified with $\mathrm{ZnO}$ and $\mathrm{Al}_{2} \mathrm{O}_{3}$ are shown in Figure 3.1.

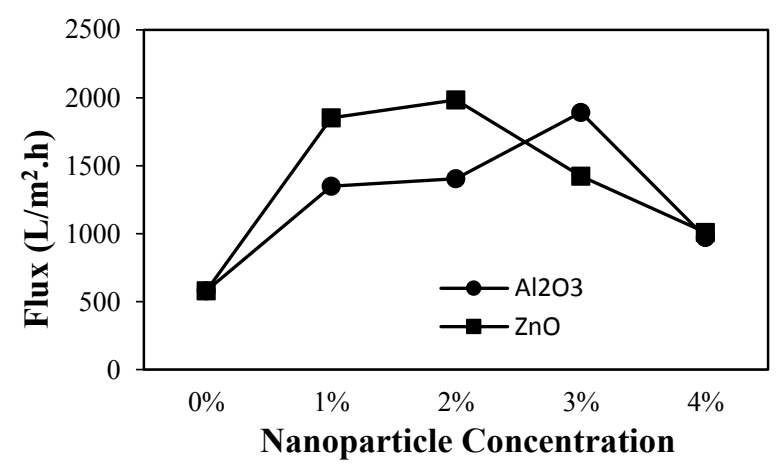

Figure 3.1 Water permeability of CA-CS membranes as function of nanoparticles concentration

It is obviously seen that compared with $0 \%$ concentration of nanoparticles, addition of both $\mathrm{ZnO}$ and $\mathrm{Al}_{2} \mathrm{O}_{3}$ has significant effect on promoting membrane permeability. These phenomena occurred might be due to complete hydrophilicity of $\mathrm{ZnO}$ and $\mathrm{Al}_{2} \mathrm{O}_{3}$. CA-CS membrane with addition of $\mathrm{ZnO}$ reached the highest flux $\left(1,984.71 \mathrm{~L} / \mathrm{m}^{2}\right.$.hour) at $2 \%$ of $\mathrm{ZnO}$ concentration, while 
addition of $\mathrm{Al}_{2} \mathrm{O}_{3}$ achieved the highest flux $(1,891.98$ $\mathrm{L} / \mathrm{m}^{2}$.hour) at $3 \%$ of $\mathrm{Al}_{2} \mathrm{O}_{3}$ concentration. It is also important to note that overdoses of both nanoparticles could decrease flux [21], as can be observed in the decrease of flux when percent concentration of $\mathrm{ZnO}$ and $\mathrm{Al}_{2} \mathrm{O}_{3}$ were $3 \%$ and $4 \%$ respectively. These results are consistent with studies conducted by Yan et al. [20] which conclude the increase of $\mathrm{Al}_{2} \mathrm{O}_{3}$ concentration along with the increase of permeate flux to certain concentration level. According to Ivars et al. [28], membrane permeability increased along with the increasing of nanoparticles in the casting solution. It caused by the affinity of nanoparticles, therefore, the porosity and pore size of modified CA-CS membranes were higher than unmodified membranes. However, the results of this study differ from research conducted by (He and Hong, [29] which states that the addition of nanoparticle the PVDF membrane reduces the flux of pure water and pore size of the membrane.

The presence of nanoparticles in the membrane matrix enhances strength and stiffness, thermal stability, permeability, hydrophilicity, flux recovery and antifouling properties of membranes [30-32]. The presence of nanoparticles improves the membrane hydrophilicity due to high surface energy thus increasing the absorption of water molecules on the membrane surface [33]. In addition, the hydrophilicity of nanoparticles also affects membrane flux. Increased hydrophilicity of the membrane surface and membrane pore could decrease the membrane fouling as it strongly interacts with water molecules and resulting greater flux $[34,35]$.

However, higher concentration of nanoparticles could negatively affect the membrane permeability due to agglomeration of the inorganic nanoparticles on the membrane surface during membrane preparation. These clumping nanoparticles as consequence of Van der Waals forces between nanoparticles caused by high surface energy to achieve stable conditions. It may clog some pores and possibly desrease the membrane hydrophilicity, thus causing decrease in the water flux $[34,36]$.

\subsubsection{Scanning Electron Microscopy (SEM)}

Figure 3.2 show SEM results from the surface of CA-CS and $\mathrm{CA}-\mathrm{CS} / \mathrm{Al}_{2} \mathrm{O}_{3}$ membranes. It was observed qualitatively that addition of $\mathrm{Al}_{2} \mathrm{O}_{3}$ influences surface morphology of each membrane. On the surfaces of CA$\mathrm{CS} / \mathrm{Al}_{2} \mathrm{O}_{3}$ membranes, both $1 \%$ and $3 \%$ concentrations appear agglomerations of nanoparticle covering the membrane pores. The increased concentration of $\mathrm{Al}_{2} \mathrm{O}_{3}$ resulted thicker agglomeration. This SEM result supports preceding explanation on the results of water permeability that the presence of nanoparticles causing clumps that covered the membrane pores.

Yan et al. [20] stated in his research that the addition of $\mathrm{Al}_{2} \mathrm{O}_{3}$ nanoparticles in PVDF membranes does not affect thesurface structure, cross section and pore size of membranes. Maximous et al. [37] also stated that there was no significant pore size difference with the addition of $\mathrm{Al}_{2} \mathrm{O}_{3}$ nanoparticles in the PES membrane. However, based on the results obtained in this study the pore size of membrane modification of $\mathrm{Al}_{2} \mathrm{O}_{3}$ nanoparticles was greater than the membranes without modification of nanoparticles. This result is in accordance with the research conducted by Liu et al. [19] which states that higher concentration of $\mathrm{Al}_{2} \mathrm{O}_{3}$ nanoparticles resulting larger pore size of membrane.

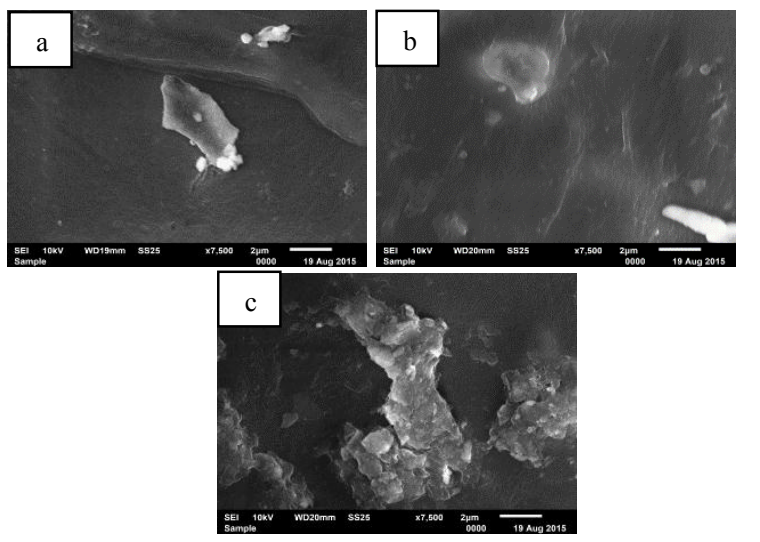

Figure 3.2 SEM of membrane surface (a) CA-CS (b) CA$\mathrm{CS} / \mathrm{Al}_{2} \mathrm{O}_{3} 1 \%$ (c) $\mathrm{CA}-\mathrm{CS} / \mathrm{Al}_{2} \mathrm{O}_{3} 3 \%$ with magnification $7.500 \mathrm{x}$

The surface morphology of the CA-CS/ZnO membrane is shown in Figure 3.3. As well as the addition of $\mathrm{Al}_{2} \mathrm{O}_{3}$, the addition of $\mathrm{ZnO}$ also resulted lumps of nanoparticles on the membrane surfaces. It is also observed that $\mathrm{CA}-\mathrm{CS} / \mathrm{ZnO}$ membranes have smaller pores than $\mathrm{CA}-\mathrm{CS} / \mathrm{Al}_{2} \mathrm{O}_{3}$ membranes. This could be caused by the presence of oxide metal nanoparticles in the polymer to increase the viscosity of the solution thereby the rate of solvent diffusion into the non-solvent during the phase inversion process decreased, which eventually led to the formation of tightly pore membranes [38].

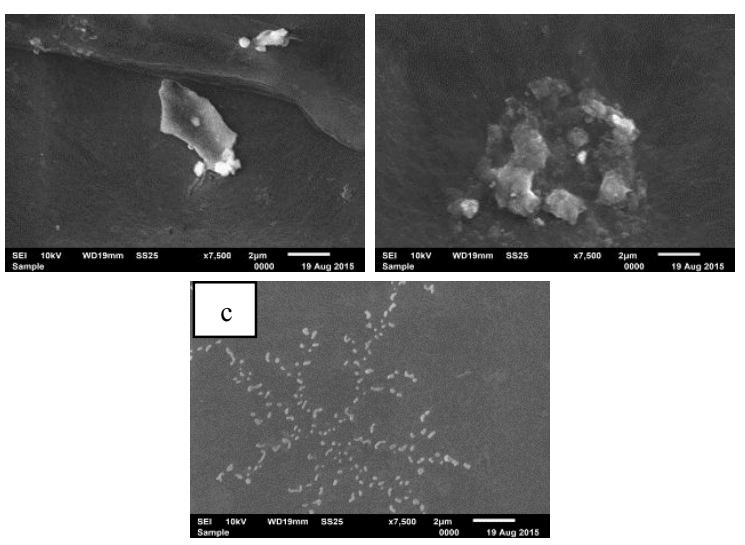

Figure 3.3 SEM of membrane surface (a) CA-CS (b) CA$\mathrm{CS} / \mathrm{ZnO} 1 \%$ (c) $\mathrm{CA}-\mathrm{CS} / \mathrm{ZnO} 2 \%$ with magnification $7.500 \mathrm{x}$

\subsection{Antibacterial Activity Test}

The anti-bacterial test was examined to find out the antibiofouling properties of CA-CS membranes after the addition of $\mathrm{Al}_{2} \mathrm{O}_{3}$ and $\mathrm{ZnO}$ nanoparticles. The antibacterial test was performed by measuring the 
diameter of the clear zone formed near membrane after $E$. coli incubation. The results are presented in Figure 3.4.
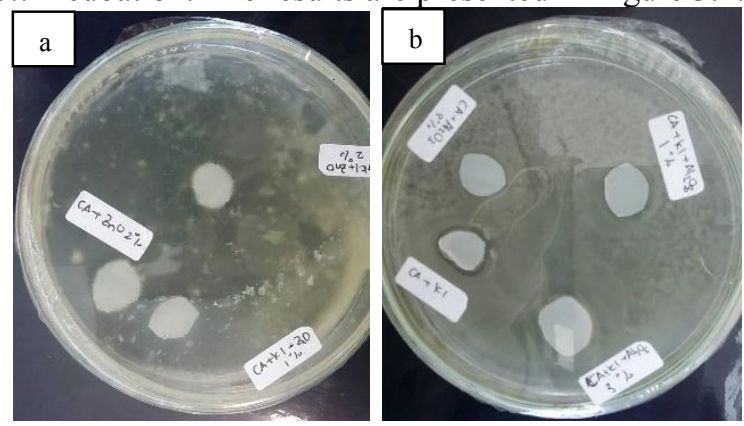

Figure 3.4 Anti-bacterial test on (a) $\mathrm{CA}-\mathrm{CS} / \mathrm{ZnO}$ membrane and (b) $\mathrm{CA}-\mathrm{CS} / \mathrm{Al}_{2} \mathrm{O}_{3}$ membrane

In the CA-CS membrane (Figure 3.4.b), the width of the clear zone formed around the membrane was $3 \mathrm{~mm}$. The width of the clear zone formed by CA-CSnanoparticle membrane was $2 \mathrm{~mm}$ and $1 \mathrm{~mm}$ for $\mathrm{Al}_{2} \mathrm{O}_{3}$ $1 \%$ and $\mathrm{Al}_{2} \mathrm{O}_{3} 2 \%$ respectively. Meanwhile, the clear zone widths formed by CA-CS membrane with $\mathrm{ZnO}$ (Figure 3.4.a) were $1 \mathrm{~mm}$ and $0.5 \mathrm{~mm}$ at concentrations of $1 \%$ $\mathrm{ZnO}$ and $2 \% \mathrm{ZnO}$ respectively. These results suggest that the effect of addition $\mathrm{ZnO}$ on membrane matrix resulted in smaller clear zone compared to CA-CS membrane which modified by $\mathrm{Al}_{2} \mathrm{O}_{3}$, while the modified CA-CS membrane with the addition of nanoparticles has a smaller clear zone than the CA-CS membrane.

Antibacterial activity can be seen from the diameter of the clear zone. The clear zone is an effective way for membrane to demonstrate antibacterial activity [39]. The greater the clear zone formed around on the membrane the better antibacterial properties. From this study, it can be concluded that the addition of nanoparticles further reduced the clear zone around membrane. In other words, the addition of nanoparticles during membrane preparation has not been successful in improving antibacterial properties. These results differ from those stated by Al-naamani et al. [24] and Malini et al. [25] that modified the chitosan membrane with the addition of $\mathrm{ZnO}$ and found that the addition of $\mathrm{ZnO}$ increased the antibacterial capacity of the membrane significantly. In another study [40], Shenghan and Ruichang, reported that the membrane of cellulose/nanoparticles produces better anti-bacterial properties than the cellulose/chitosan membrane. However, in these results, it is seen that higher nanoparticle concentrations resulted smaller inhibition zones. This might be due to the accumulation of nanoparticles added to the membrane which further decreased their antibacterial activity.

\section{Conclusion}

Modification of CA-CS membrane by adding $\mathrm{ZnO}$ and $\mathrm{Al}_{2} \mathrm{O}_{3}$ increased flux. The maximum flux of the modified membrane was reached by $2 \% \mathrm{ZnO}\left(1,984.71 \mathrm{~L} \cdot \mathrm{m}^{-2} \cdot \mathrm{h}^{-1}\right)$ and $3 \% \quad \mathrm{Al}_{2} \mathrm{O}_{3} \quad\left(1,891.98 \mathrm{~L} \cdot \mathrm{m}^{-2} \cdot \mathrm{h}^{-1}\right)$. In addition, the presence of nanoparticles also enhanced hydrophilicity of CA-CS membranes. The SEM results showed that addition nanoparticle during phase separation process has not occurred perfectly, evidenced by the presence of the agglomerations of nanoparticles on membrane surfaces. The higher the concentration of nanoparticles, the more obvious the appearance of the lumps. An antibacterial test using inhibition zone method was performed. Nevertheless, it produced unideal result, where no clear zone around the membrane were visible.

The authors would like to thanks to Engineering Faculty, Diponegoro University for the financial support of this study.

\section{References}

[1] G. Kang, Y. Cao. J. Membr. Sci. 463, 145-165 (2014)

[2] J. Hong, Y. He. Desalination 332, 67-75 (2014)

[3] J. Kim, B.V. Bruggen. Environ. Pollut. 158, 23352349 (2010)

[4] D. Bhongsuwan and T. Bhongsuwan, 2008. J. Nat. Sci. 42, 311 - 317 (2008)

[5] J. Puls, S.A. Wilson, D. Holter.J. Polym. Environ. 19, 152-165 (2011)

[6] J. Hong, Y. He. Desalination 302, 71-79 (2012)

[7] L.H. Kim, M.S. Shin, S. Kim, C. Kim, K. Chae, In. S. Kim. J. Membr. Sci. 477, 86-92 (2015)

[8] L. Dong, H. Yang, S. Liu, X. Wang, Y.F Xie. Desalination 365, 70-78 (2015)

[9] C.X Liu, D.R Zhang, Y. He, X.S. Zhao, R. Bai. J. Membr. Sci. 346 .121-130 (2010)

[10] N. Hilal, V. Kochkodan, L. Al-Khatib, T. Levadna. Desalination. 167, 293-300 (2004)

[11] H. Rajabi, N. Ghaemi, S.S. Madaeni, P. Darael, B. Astinchap, S. Zinadini, S.S. Razavizadeh. Appl. Surf. Sci. 349, 66-77 (2015)

[12] T.C. Yang, C.C. Chou, C.F. Li. Int. J. Food Microbiol. 97, 237-245 (2005)

[13] G. Ma, D. Yang, Y. Zhou, M. Xiao, J.F. Kennedy, J. Nie. Polym. 74, 121-126 (2008)

[14] H. Mellegard, S.P. Strand, B.E. Christensen, P.E. Granum, S.P. Hardy. Int J. Food Microbiol 148, 48$54(2011)$

[15] C. Qin, H. Li, Q. Xiao, Y. Liu, J. Zhu, Y. Du. Carbohyd. Polym. 63, 367-374 (2006)

[16] T. Istirokhatun, N. Rokhati, D. Nurlaeli, N.N. Arifianingsih, Sudarno, Syafrudin, H. Susanto. Int. J. Environ. Sci. Technol. 10, 56-67 (2017)

[17] F. Kara, E.A Aksoy, Z. Yuksekdag, N. Hasirci, S. Aksoy. Carbohyd. Polym. 112, 39-47 (2014)

[18] J.G. Ivars, M.I. Iborra-Clar, M.I. Alcania-Miranda, B.V. Bruggen. J. Membr. Sci. 492, 709-722 (2015)

[19] F. Liu, M.R.M. Abed, K. Li. J. Membr. Sci. 366, 97-103 (2011)

[20] L.Yan, Y.S. Li, C.B. Xiang, S. Xianda. J. Membr. Sci. 276, 162-167 (2006)

[21] S. Liang, K. Xiao, Y. Mo, X. Huang. J. Membr. Sci. 394-395, 184-192 (2012)

[22] D. Sharma, J. Rajput, B.S. Kaith, M. Kaur, S. Sharma. Thin Solid Films. 519, 1224-1229 (2010)

[23] G.S. Dhillon, S.Kaur, S.K. Brar. Int. Nano. Lett. 4, 107 (2014)

[24] L. Al-naamani, S. Dobretsov, J. Dutta, J.G. Burgess. Chemosphere. 168, 408-417 (2017) 
[25] M. Malini, M. Thirumavalavan, W.Y. Yang, J.F. Lee, G. Annadurai. Int. J. Biol. Macromol. 80, 121 129 (2015)

[26] T. Istirokhatun, R. Rachmawaty, M. Merriyani, N. Rokhati, H. Susanto. IOP Conf. Ser.: Earth Environ. Sci. 55 (2017)

[27] Y. Ma, T. Zhou, C. Zhao. Carbohydr. Res. 343 (2008)

[28] J.G. Ivars, M.I.A. Miranda, M.I.I. Clar, J.A.M. Roca, L.P. Alcaniz. Sep. Purif. Technol. 128, 45-57 (2014)

[29] Y. He, and J. Hong. Adv. Mat. Res. 311-313; 1818 1821 (2011)

[30] M.K. Shinha, and M.K Purkait. J. Membr. Sci. 437, 7-16 (2013)

[31] A.Razmjou. J. Mansouri, V. Chen. J. Membr. Sci. 378, 73-84 (2011)

[32] T.A. Saleh, and V.K. Gupta. Sep. Purif. Technol. 89, 245-251 (2012)

[33] S. Balta, A. Sotto, P. Luis, L. Benea, B.V.D. Bruggen, J. Kim. J. Membr. Sci. 389, 155-161 (2012)

[34] Y.S. Li, L. Yan, C.B. Xiang, L.J. Hong. Desalination 196, 76-83 (2006)

[35] L. Ahmad, A.A. Abdulkarim, B.S. Ooi. Chem Eng Jour 223, 246-267 (2013)

[36] J.M. Arsuaga, A.Sotto, G.del Rosario, A. Martinez, S. Molina, S.B. Teli, J. de Abajo. J. Membr. Sci. 428, 131-141 (2013)

[37] N. Maximous, G. Nakhla, W. Wan, K. Wong. J. Membr. Sci. 341, 67-75 (2009)

[38] Y. Wang, Q. Zhang, C.L. Zhang, P. Li. Food Chem 132, 419-427(2012)

[39] Z. Cao, Z. Shen, X. Luo, H. Zhang, Y. Liu, N. Cai, Y. Xue, F. Yu. Carbohyd Polym. DOI. 10.1016/j.carbpol.2017.03.012 (2017)

[40] G. Shenghan and G. Ruichang. Chem. Res. Chin. Univ. DOI:10.1007/s40242-017-6423-4 